\title{
Farmers' perception of agricultural cooperatives: the case of Şanlıurfa, Turkey
}

\author{
Mehmet Reşit Sevinç ${ }^{1 *}$

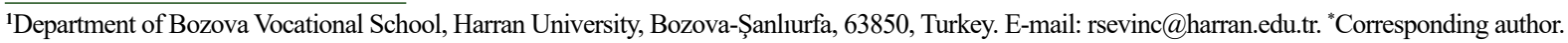

\begin{abstract}
Turkey. However, it has only $0.62 \%$ of the total number of cooperatives in the country. This study aimed to determine the perceptionsof farmers in Sanlurfa regarding agricultural cooperatives and the factors affecting them. The main research material was obtained through face-to-face surveys involving farmers in Şanluurfa selected by a simple random sampling method. The sampling volume was determined with a $95 \%$ confidence limit and a $5 \%$ error margin. Multiple regression analysis was used in Stata software. According to the results of the research, 39.7\% of the participants were cooperative members and more than half of them were not active members. Of the participants, $30.3 \%$ had a positive perception of cooperatives, $36.82 \%$ were undecided, and $32.88 \%$ had negative opinions. Age, marital status, non-agricultural income, experience, social security, farmer registration system, cooperative membership, and land variables positively affected farmers' perceptions. However, the variables of education, income, and union membership had negative effects on farmers'perceptions. No statistically significant relationship was reported between a farmer's perception and any of the following variables: the number of people that make up the farmer's household, the number of individuals engaged in agriculture and non-agricultural work in the family, and the status of the farmer's lease. Conceptual, local, cultural, educational, and structural problems related to cooperatives exist in Sanluurfa.These issues need to be given more attention by the public. This research is the first study on this subject to be conducted in Şanluurfa.
\end{abstract}

Key words: agricultural cooperatives, farmer memberships, farmer perception, Şanluurfa- Turkey.

A percepção dos agricultores sobre as cooperativas agrícolas: o caso de Şanlıurfa, Turquia

RESUMO: Sanliurfa é a província com a terceira maior área agrícola da Turquia. No entanto, possui apenas 0,62\% do número total de cooperativas no país. Este estudo teve como objetivo determinar as atitudes e a percepção dos agricultores em Şanluurfa em relação às cooperativas agrícolas e os fatores que as afetam. O principal material de pesquisa foi obtido através de pesquisas presenciais envolvendo agricultores em Şanlurfa, selecionados por um método simples de amostragem aleatória. O volume amostral foi determinado com um limite de confiança de $95 \%$ e uma margem de erro de 5\%. A análise de regressão múltipla foi utilizada. De acordo com os resultados da pesquisa, 39,7\% dos participantes eram cooperados e mais da metade deles não eram ativos. Dos participantes, 30,3\% tinham percepção positiva das cooperativas, 36,82\% estavam indecisos e 32,88\% tinham opiniões negativas. Idade, estado civil, renda não agrícola, experiência, previdência social, sistema de registro de agricultores, participação em cooperativas e variáveis de terra afetaram positivamente as atitudes dos agricultores. No entanto, as variáveis educação, renda e filiação sindical tiveram efeitos negativos nas atitudes dos agricultores em relação às cooperativas. Não foi encontrada relação estatisticamente significante entre a percepção das cooperativas por parte de um agricultor e qualquer uma das seguintes variáveis: número de pessoas que compõem a família do agricultor, número de indivíduos envolvidos na agricultura e trabalho não agricola na familia e status de arrendamento do fazendeiro. Problemas conceituais, locais, culturais, educacionais e estruturais relacionados às cooperativas existem em Şanliurfa. Esta pesquisa é o primeiro estudo sobre esse temarealizado em Şanluurfa.

Palavras-chave: cooperativas agricolas, associações de agricultores, percepção dos agricultores, Şanluurfa- Turquia.

\section{INTRODUCTION}

Agriculture has strategic importance for all countriesthat deals with the production of plants and animal to meet the need for food, increase plant and livestock quality and productivity, preserve the produce even in inappropriate conditions, and process, evaluate, and market the produce (AYDOGDU, 2017; YAVUZ \& DILEK, 2019). In many countries, the agricultural sector is faced with numerous challenges such as low productivity, lack of capital, insufficient support, inadequate organization, insufficiency of farmers, and lack of competitiveness with other sectors (RAHMAN, 2017; SEVINÇ, 2018; KAKAR et al., 2019; MATHUR \& KASHYAP, 2000). Agriculture has long ceased to be considered as the major economic sector and its contribution to national economies is often underrated or neglected (LOIZOU et al., 2019). Everyone knows that farming is a risky sector. Food prices fluctuate from year to year and production levels can be similarly volatile. These factors often combine to make farmers' income very unstable. 
Due to the low-income levels of farmers in general, organized structures are needed to improve their living conditions, level of welfare, and ensure the development of rural. One of the problems of agricultural production is that farmers do not have sufficient organized structure (LEAO et al., 2018). Globally, a large part of the problems in the agricultural sector stems from the inability of farmers to act together. It is only possible to overcome the problems with the conscious organization (ÇIKIN, 2016; SEVINÇ, 2018; CANÇELİK et al., 2020). A cooperative is an autonomous association of persons united voluntarily to meet their common economic, social, and cultural needs and aspirations through a jointly-owned and democratically-controlled enterprise (ZEULI\&CROPP, 2004). A cooperative can reduce risks by offering farmers the opportunity for integration during farming (SEXTON \& ISKOW, 1988), and contribute to members in terms of income due to the advantage of providing low-cost input (MCGREGOR, 1977). There is a positive impact on productivity and supply when there are cooperatives in rural areas where lack of access to the cities is a major obstacle (VANDEPLAS et al., 2013), to increase agricultural performance and the welfare of farmers' households (MA \& ABDULAI, 2016). If agricultural cooperatives did not exist, without the provision of credit and modern inputs, small farmers would experience declining yield (ABDELRAHMAN \& SMITH, 1996).

While in 2001 there was a total of 40.97 million hectares (ha) of agricultural land in Turkey, that area decreased to 37.82 million hain 2018resulted in a decrease in the number of farmers by 3.5 million (SEVINÇ et al., 2019).Although, this situation occurs due to many reasons, the most important reason is the increase in the input costs, the decrease in profitability in subsistence farming resulted in in-migration from rural to urban. In Turkey,23.09 million ha of agricultural land were cultivated in 2019. (TURKSTAT, 2019). Although, the decrease in agricultural areas, with the increase of irrigated areas and the spread of industrial agriculture, the production amounts increased. While the crop production value in Turkey was 20.01 billion Turkish Liras (TL) in 2001, it rose to 195.83 billion in 2019.In the same years, the value of livestock increased from 8.30 billion TL to 165.31 billion TL and the value of animal products increased from 6.06 billion TL to 93.91 billion TL (TURKSTAT, 2020a). It cannot be said that these increases in agricultural production value were a reflection of small and subsistence farming farmers' income. In
$2006,7.11 \%$ of the disposable income which is the money that can be used outside of food and basic subsistence needs of households in rural areas were the income of agricultural entrepreneurs' in Turkey. This rate decreased to $6.34 \%$ in 2010 and $4.3 \%$ in 2018 (TURKSTAT, 2020b). Nowadays, the need for organized structure has increased even more for both consumers and producers, as agricultural produce mostly pass through marketing channels and become international trade commodities (GTHB, 2013). Globally, many countries also apply tax reductions or exemptions to agricultural cooperatives, along with agricultural supports and grants, to increase organization in agricultural production(KOÇTÜRK, 2006; RIBAŠAUSKIENE் et al., 2019; YU, 2019). For agricultural activities to be sustainable in the countryside, farmers should earn a satisfactory income (DOĞAN et al., 2020). However, producers are mainly at a disadvantage in the sector due to the production phase input supply and financing, product marketing determination of market prices and in the distribution stage, and the mostly small business structure of agricultural holdings in Turkey.

According to data from the International Co-operatives Alliance, cooperatives globally had over 1 billion partners in 2016.In other words, one out of seven people in the world was a cooperative partner (INTERNATIONAL CO-OPERATIVE ALLIANCE, 2017). In the European Union, on average one out of three people is known to be a cooperative partner (GÜREŞÇI \& GÖNÇ, 2017).In the mentioned period, $9.1 \%$ of the population of Turkey was a member of a cooperative and more than half of them were not active members(ANONYMOUS, 2017). The number of cooperatives and their partners for agricultural purposes established in 2018 in Turkey are presented in table 1 .

Some studies have revealed that cooperatives contribute positively towards the eradication of poverty in rural areas and the enhancement of people's welfare. Besides, it has been determined that cooperative organizations formed for regional and rural developments bring about successful results (GETNET\& ANULLO, 2012; KUMAR et al., 2015; VERHOFSTADT \& MAERTENS, 2015; MA \& ABDULAI, 2016).

Turkey consists of eighty-one provinces and seven geographical regions.Şanluurfa is the province with the third-largest agricultural area (GAP IDARESI, 2019). The GAP project is the most important regional development project based on water and land resources in Turkey where Şanliurfa has the biggest potential in terms of both agricultural 
Table 1 - The number of agricultural cooperatives in Turkey (ANONYMOUS, 2020).

\begin{tabular}{lcc}
\hline Cooperative types & Number of organizations & Number of partners \\
\hline Agricultural Development Cooperative & 8,173 & 842,563 \\
Irrigation Cooperative & 2,497 & 295,984 \\
Fisheries Cooperative & 522 & 29,972 \\
Beet Planters Cooperative & 31 & $1,638,981$ \\
Agricultural Credit Cooperative & 1,767 & $1,082,978$ \\
Total & 12,990 & $3,890,478$ \\
\hline
\end{tabular}

land and livestock in the GAP (AYDOGDU \& YENIGÜN, 2016). Although, cooperatives have great beneficial advantages for farmers, cooperative activities are not common enough in Şanlıurfa. While only $1.03 \%$ of the total number of cooperatives in Turkey were in Şanlıurfa in 2016 and declined to $0.62 \%$ in 2018 (ANONYMOUS, 2020). There were 81 farmer organizations, including 5 breeder unions, 9 producer unions, and 67 agricultural cooperatives, in Şanlıurfa in 2018, but more than half of them are now inactive (SEVINÇ, 2018; CANÇELIKK etal., 2020). The objective of the research was to determine the perceptions of farmers in Şanlıurfa regarding agricultural cooperatives and the factors affecting them.

\section{MATERIALS AND METHODS}

The main material used in this study was the primary data obtained from farmers in Şanlıurfa by surveywho were selected through a simple random sampling method from among the 59,195 farmers registered in the Şanlıurfa State Farmer Registration System in 2018. The sample volume was determined using the sample size and a tolerable sampling error table (BAYRAM, 2017), with a 95\% confidence level and $5 \%$ error margin. The sample volume was 382 but 388 questionnaires were used in the analysis to be on the safe side.

The simple linear regression model may be suitable for many situations, but two or more explanatory variables are required to explain the dependent variable of many models in real life (KALAYCI, 2010). This is called multiple regression analysis. Each of these explanatory variables is a somewhat dependent variable of the subject under the research. In this case, the used number of dependent variables increases for the research. The reduction of these explanatory variables, which are correlated with each other's, to a single variable (latent variable) is called the first component. The principal component is a new variable (an eigenvector, represented by an axis), resulting from the combination of the original variables, which contribute differently (in terms of the proportions of the variance brought by each one of them) to form this new axis (BORCARD et al.,2018). Variance and eigenvalue values are checked for the first component to be used safely. If these values are reliable, the first component can be used as a dependent variable in the analysis. This is called principal component analysis which is a method that allows to reveal and predict relationships that have not been previously revealed(ÖZDAMAR, 2013).In the study, the principal component analysis was first applied to the data, and then multiple regression analyses done using the Stata software program. The principal component analysis is a technique of creating new variables which means that the linear combination of original variables. So it is a data reduction method. Calculated as follows (1) (SHARMA, 1996; JOHNSON \& WICHERN, 2007).

$$
\begin{gathered}
P C_{1}=a_{1}^{\prime} X=a_{11} X_{1}+a_{12} X_{2}+\cdots+a_{1 p} X_{p} \\
P C_{2}=a_{2}^{\prime} X=a_{21} X_{1}+a_{22} X_{2}+\cdots+a_{2 p} X_{p} \\
\vdots \\
P C_{p}=a_{p}^{\prime} X=a_{p 1} X_{1}+a_{p 2} X_{2}+\cdots+a_{p p} X_{p}
\end{gathered}
$$$$
P C_{1}, \quad P C_{2}, \ldots, \quad P C p \text { shows the main }
$$
components, and app $\mathrm{p}^{\text {th }}$ in the main component $\mathrm{p}^{\text {th }}$ represents the importance of the variable. The first main component is the component that explains the variance at the highest level in the analysis (2).

$$
\operatorname{Var}\left(P C_{1}\right)=a_{1}^{\prime} \sum a_{1}
$$

It is the component that maximizes equality. First principal component, linear combination $a_{1}^{\prime} X$ that maximizes (3) ( SHARMA, 1996; JOHNSON \& WICHERN, 2007);

$\operatorname{Var}\left(a_{1}{ }^{\prime} X\right)$ subject to $a_{1}$ ' $a_{1}=1$

Regression analyses are a set of statistical techniques that allow one to assess the relationship 
between one dependent and several independent variables (TABACHNICK \& FIDELL, 2007). It is formulated as follows (4):

$Y=\beta_{0}+\beta_{1} X_{1}+\beta_{2} X_{2}+\ldots \ldots .+\cdots \beta_{n} X_{n}+\varepsilon$

$Y$ represents the dependent variable, $\beta_{0}$ is a constant, $\beta_{0} \ldots \beta_{n}$ are the regression coefficients of the variables, $X_{1} \ldots X_{n}$ are the independent variables, and $\varepsilon$ represents the error term.

The research aimed to determine the perceptions of farmersregarding the contribution of cooperatives towards increasing income from agricultural production.In this context, to determine perceptions, the statements were given to the farmers and asked to indicate their degree of participation. Accordingly, cooperatives help provide easy and cheap inputs,timely supply of inputs used in production, help in making agriculture better and sustainable, marketing and production risks have decreased with cooperatives and cooperatives are effective in selling products at competitive prices were chosen as givenvariables. These variables, which are given as a positive expression that will provide income increase based on agricultural organization, can turn into a single factor that directly affects the agricultural income of the farmer when they become a whole.Then, these given variables were converted to one variable through the first component, which became the dependent variable. That isagricultural cooperatives contribute positively to increasing the agricultural income of the farmer. Thesocioeconomicindependent variables used in the model are given in table 2 .

\section{RESULTS AND DISCUSSION}

The sample volume comprised only male farmers due to the culture and patriarchal structure of the research area. Almost $85 \%$ of the participants were in the farmer registration system and 59\% were members of farmers' associations (irrigation union, producer and breeder associations, etc.), while the membership rate for agricultural cooperatives was

Table 2 - Results of the multiple regression analysis.

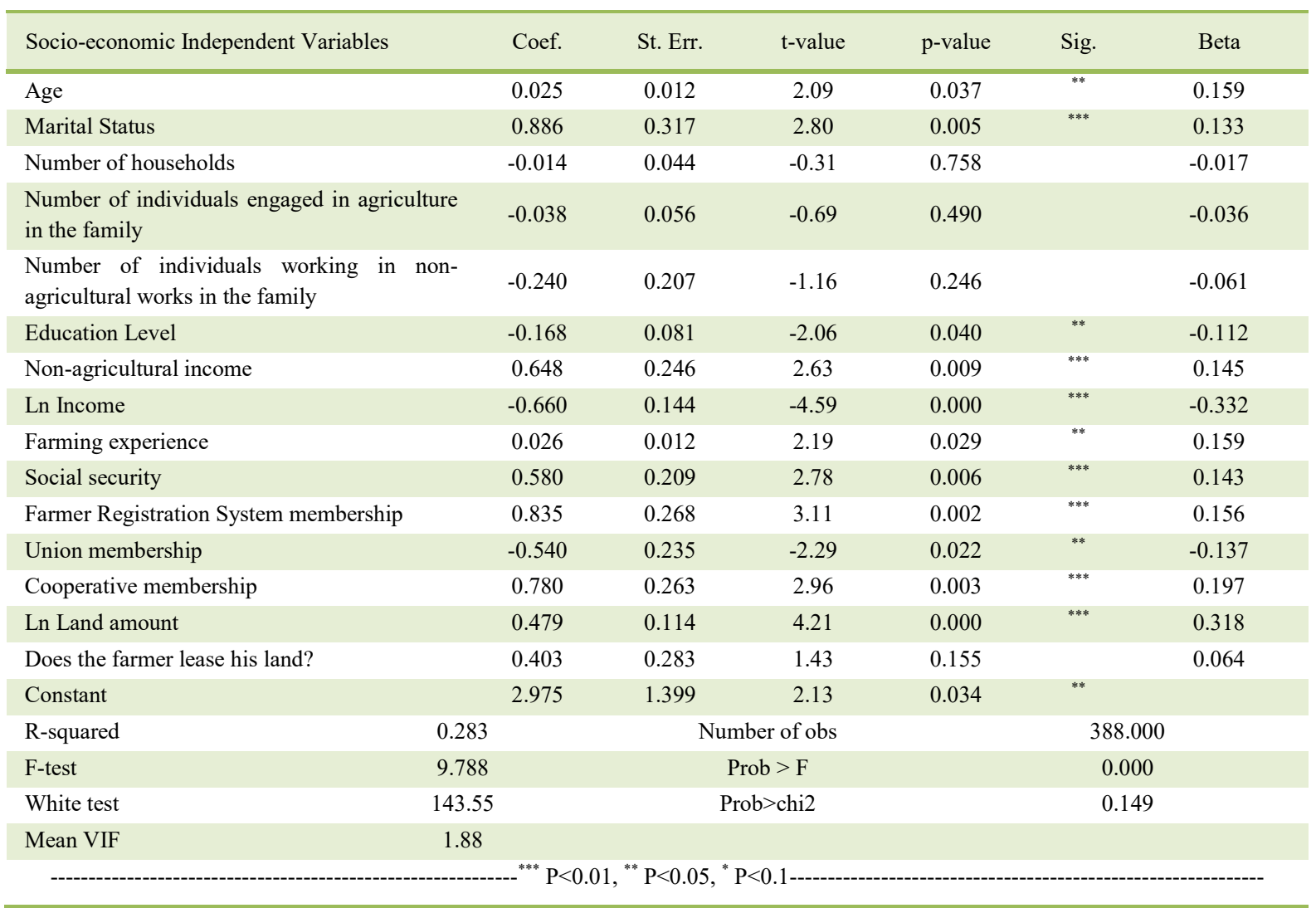

Ciência Rural, v.51, n.3, 2021. 
$39.7 \%$ and more than half of them stated that they were not active members. The descriptive statistics of the participants are given in table 3 .

The degree of participation of the farmers in the given statements which are response variables is shown in table 4. The Cronbach's Alpha coefficient is used for the reliability analysis of the answers given by the participants. If it is greater than 0.8 , it indicates that the survey has high reliability. It was found for these given variables as 0.914 .

In a study conducted in Romania, it was determined that one of the most important reasons why farmers became members of cooperatives was to reduce input costs. Farmers, as cooperative members, significantly reduced costs because they used machines and equipment belonging to the cooperative (TUREK et al., 2012). In a study conducted in Nicaragua, farmers benefit from cooperative activities ranging from input supply to marketing and that these benefits positively affected the farmers' views about cooperatives (KROEKER, 1995). Similar positive results were obtained in studies conducted in Thailand and Ethiopia (FRANCESCONI \& HEERINK,
2010; THUVACHOTE, 2011). The positive effect varies with farm size, distance to the market, and the availability of labour in the household and could be turned to be negative for very small farms (VERHOFSTADT \&MAERTENS, 2015). It has also been determined that cooperatives, which are not managed by competent persons and are not subject to a transparent audit, cannot provide their partners with benefits such as reduction of input costs, marketing advantage, and income increase (KÖROĞLU, 2003).

The variables (given statements) showed a high correlation among themselves. For this reason, the principal component analysis was applied with the idea that these variables could be collected under a single component (PRIMPAS et al., 2010; BERNI et al., 2011). As a result of the analysis, it was determined that the explained variance rate of the first component was 0.746 . At the same time, the eigen value of this component was 3.731 , which is greater than 1 and explains more than $2 / 3$ of the total variance. In line with these results (SHARMA, 1996; TABACHNICK \& FIDELL, 2007; ÖZDAMAR, 2013), the analysis was continued with the scores of the first component.

Table 3 - The descriptive statistics of the participants.

\begin{tabular}{|c|c|c|c|}
\hline Variable & Definition & Mean & Std. Dev \\
\hline Age & Year & 45.75 & 12.306 \\
\hline Marital Status & If the farmer: single $1(9.28 \%)$, if not $0(90.72 \%)$ & 0.09 & 0.290 \\
\hline Household Number & The household number of the farmer's family & 6.71 & 2.444 \\
\hline $\begin{array}{l}\text { Number of household } \\
\text { working in agriculture }\end{array}$ & The household number of agriculture workers & 2.30 & 1.846 \\
\hline $\begin{array}{l}\text { Nonagricultural workers } \\
\text { in household }\end{array}$ & If yes $=1(41.75)$, no=0 $(58.25)$ & 0.41 & 0.493 \\
\hline Education & $\begin{array}{c}\text { The education level of the farmer, if illiterate } 1,2 \text { for literate, } 3 \text { for primary } \\
\text { school graduates, } 4 \text { for secondary school graduates, } 5 \text { for high school } \\
\text { graduates, } 6 \text { for university graduates }\end{array}$ & 3.46 & 1.290 \\
\hline Non-agricultural income & If the farmer has non-agricultural income is $1(25.26 \%)$, if not is $0(74.74 \%)$. & 0.25 & 0.435 \\
\hline Income & Average annual agricultural income (TL/year) & 120,716 & 150,201 \\
\hline Experience & Farmer's experience of farming (year) & 22.29 & 11.72 \\
\hline Social security & If yes $=1(65.21 \%)$, no $=0(34.79 \%)$ & 0.65 & 0.476 \\
\hline $\begin{array}{l}\text { Farmer registration } \\
\text { system membership }\end{array}$ & If yes $1(84.54 \%), \mathrm{no}^{\prime}=0(15.46 \%)$ & 0.84 & 0.362 \\
\hline $\begin{array}{l}\text { Membership of an } \\
\text { agricultural association }\end{array}$ & $\begin{array}{l}\text { If the farmer has a membership of any agricultural association is } 1(58.51 \%) \text {, if } \\
\text { there is no membership is } 0(41.49 \%) \text {. }\end{array}$ & 0.58 & 0.493 \\
\hline $\begin{array}{l}\text { Membership of } \\
\text { agricultural cooperatives }\end{array}$ & $\begin{array}{l}\text { If the farmer has a membership of any agricultural cooperative is } 1(39.69 \%) \text {, } \\
\text { if there is no membership is } 0(60.31 \%) \text {. }\end{array}$ & 0.39 & 0.489 \\
\hline Land Amount & Amount of land cultivated by the farmer (Hectare) & 23.611 & 536.877 \\
\hline $\begin{array}{l}\text { Does the farmer lease his } \\
\text { land? }\end{array}$ & If yes $=1(10.57 \%)$, no $=0(89.43 \%)$ & 0.10 & 0.307 \\
\hline
\end{tabular}

Ciência Rural, v.51, n.3, 2021. 
Table 4 - The degree of participation (responsens) of the farmers in the given statements.

\begin{tabular}{|c|c|c|c|}
\hline Given statements to farmers to indicate their participation (\%) & Yes & Undecided & No \\
\hline Cooperatives help provide easy and cheap inputs & 35.1 & 34.6 & 30.3 \\
\hline Cooperatives provide timely supply of inputs used in production & 28.8 & 37.1 & 34.1 \\
\hline Cooperatives help in making agriculture better and sustainable & 32.2 & 37.9 & 29.9 \\
\hline Marketing and production risks have decreased with cooperatives & 26.9 & 38 & 35.1 \\
\hline Cooperatives are effective in selling products at competitive prices & 28.5 & 36.5 & 35 \\
\hline
\end{tabular}

In the study, multiple regression analysis was applied to the index values (the scores of the first component created based on five variables, i.e. given statements)of the contribution of cooperatives to increasing the agricultural income of the farmers. Results of this analysis are given in table 2 .

In table 2 , the $\mathrm{R}^{2}$ value is 0.283 which shows how much of the change in the dependent variable is explained by the socio-economic independent variables as a percentage. It explains the effect of the selected socio-economic independent variables on the dependent variable in the model. The F value, which tests the significance of the model as a whole, is 9.788 and its $p$-value is $0.000<0.05$. According to this result, it can be said that the model was meaningful as a whole. The White test helps us to understand if there was a variance problem. Since the $p$-value of it is greater than $0.149>0.05$, it is seen that there was no variance problem in the model. VIF values help us to understand whether there were multiple connection problems. If the VIF values were between 1 and 5, there would be no need for correction in the model. The maximum VIF value obtained from the model was 3.01 and the average of the VIF values was 1.88 . According to this value, it is possible to say that there was no multiple connection problem in the model. To determine which of the socio-economic independent variables in the model had the most effect on the dependent variable which was one of the aims of the research. For this, the coefficients compare as absolute values if the measurement units of the independent and the dependent variables were the same. But if the independent and dependent variables had different units of measurement, then it would not be correct to compare the coefficient sizes. This required calculating beta values (standardized regression coefficients) which shows the importance order of the independent variables regardless of the value sign (MERT, 2016). The socio-economic independent variable that takes the highest absolute value is the most effective. According to the results obtained, the socio-economic independent variable with the highest beta value in the model was the income and followed by the land. Finally, $t$ and $p$ values in the table help us to understand the significance level of the independent variables included in the model.

The coefficients of the variables in table 2 were examined. Accordingly, it was determined that a statistically positive and significant relationship existed between age $(p=0.037$; coef. $=0.025)$ and the dependent variable. In a study conducted in Ethiopia, gender and age were strong determinants of membership of agricultural cooperatives, where middle-aged and older men tended to belong to cooperatives (ABEBAW \& HAILE, 2013). In other studies conducted in Ethiopia, age was again determined to be an effective factor in the participation of farmers in the organization of agricultural cooperatives (BERNARD et al., 2008; BERNARD \& SPIELMAN, 2009). In a study conducted in Poland, age was found to be an effective factor in cooperative membership and management (BANASZAK, 2008). In a study conducted in the TRA region of Turkey, there was a greater positive perception of cooperative activities with increasing age of farmers, who preferred to solve problems they encountered in food production in partnership with organizations as they got older (ERTEK et al., 2016). A similar result was obtained from a study in China, and the attitudes of young farmers towards cooperative activities were negative (MA \& ABDULAI, 2016). In a study of rice producers in China, it was found that the older farmers viewed cooperative activities more positively (HOKEN \& SU, 2018). There was a statistically positive significant relationship between marital status $(p=0.005$; coef. $=0.886)$ and the dependent variable. In a study conducted in Poland, it was determined that marital status is an effective factor in cooperative membership and management (BANASZAK, 2008). A statistically significant positive relationship was 
found between non-agricultural income $(\mathrm{p}=0.009$; coef. $=0.648$ ) and the dependent variable. A study of the economic structure of all cooperative partners in Turkey was carried out and Şanliurfa generated the highest non-agricultural income from membership of cooperatives by its farmers (ŞAHIN et al., 2013).

A statistically significant positive correlation was found between a farming experience $(\mathrm{p}=0.029$; coef. $=0.026)$ and the dependent variable. In studies conducted in Ethiopia, farmer's experience have a positive effect on participation in a cooperative organization (BERNARD et al., 2008; BERNARD \& SPIELMAN, 2009; ABEBAW \& HAILE, 2013). There were positive statistically significant relationships between the dependent variable and each of the following independent variables: social security $(p=0.006$; coef. $=0.580)$, farmer registration system membership $(p=0.002$; coef. $=0.835)$, and cooperative membership $(\mathrm{p}=0.003$; coef. $=0.780)$. In a study conducted in Sudan, it was determined that membership of cooperatives positively influenced farmers' attitudes. The comparison between agricultural cooperative members and non-members showed that members earned higher incomes than non-members (ABDELRAHMAN \& SMITH, 1996). Social environment and togetherness are important in cooperative membership and affect the attitudes of members. In Turkey, one of the factors that positively influence farmers' decisions to join cooperatives in the Southeastern Anatolia Region is the need to have effective communication and great social relationships with other farmers (KARLI et al., 2006). A study was conducted to determine the functions and benefits of cooperatives in Nicaragua. According to the results obtained, in some cooperatives, the members were only united by the joint credit, services, machinery, transport, or marketing. Nevertheless, in many cooperatives, they shared almost everything(KROEKER, 1995). In a study conducted in Thailand, it was determined that agricultural cooperatives had a positive effect on rural development, increased the agricultural income of farmers, and created positive changes in social security in rural areas (THUVACHOTE, 2011).

A statistically positive significant relationship was found between land amount $(\mathrm{p}=0.479$; coef. $=0.000$ ) and the dependent variable, contributing to an increase in the agricultural income of farmers. In a study conducted in Kenya, it was determined that the amount of land had some effect on cooperative membership. The size of the landholding had a positive and significant effect on the membership, and each additional acre of land owned increased the probability of membership by almost $4.3 \%$. But the probability of membership started to decrease again for farms larger than 11 acres (FISCHER \& QAIM, 2012). In Turkey, the land amount is an effective factor in cooperative membership in the Southeastern Anatolia Region based on derived income (KARLI et al., 2006). In a survey of the province of Burdur, which is located in the west of Turkey, the land size was found to influence cooperative membership (ALÇİÇEK \& KARLI, 2016). Conversely, a study in Ethiopia reported that a member must have at least a medium-sized piece of land to obtain sufficient commercial income from the cooperative. In other words, cooperatives should not be seen as a means to ensure the participation of the poorest of the poor farmers (FRANCESCONI \& HEERINK, 2010).

There was a statistically negative significant relationship between the dependent variable and each of the following independent variables: education $(p=0.040$; coef. $=-0.168)$, agricultural income $(\mathrm{p}=0.000 ;$ coef. $=-0.660)$, and farmers' union membership $(\mathrm{p}=0.022$; coef. $=$ -0.540 ). Similar results were obtained by studies on cooperatives in Southeastern Anatolia and the province of Burdur, both in Turkey. As education and income increased, farmers' attitudes towards cooperative activities became more negative (KARLI et al., 2006; ALÇIÇEK \& KARLI, 2016). On the contrary, studies conducted in Ethiopia reported a positive relationship between educational status and membership of cooperatives (BERNARD et al., 2008; BERNARD \& SPIELMAN, 2009; ABEBAW \& HAILE, 2013). Again, in a study conducted in Poland, education was found to be one of the positive factors affecting cooperative membership and management (BANASZAK, 2008).

Finally, there was no statistically significant relationship between the dependent variable and any of the following independent variables: the size of a farmer's households $(p=0.780$; coef. $=-0.014)$, the number of individuals engaged in agriculture in a farmer's family ( $p=0.490$; coef. $=-0.038$ ), the number of individuals working in non-agricultural jobs in the family ( $p=0.246$; coef. $=-0.240)$, and the tenure on which the farmland is held $(\mathrm{p}=0.155$; coef. $=-0.403)$.

\section{CONCLUSION}

Agricultural cooperatives exist in almost every country in the world, regardless of their levels of development. These cooperatives make important contributions to food security, rural development, and poverty reduction in the countries where they exist. 
Cooperatives play important roles in agriculture - at all stages of food production, distribution, and marketing. They provide very important support especially for small-scale enterprises and low-income farmers from production to marketing. Conversely, organized structures like cooperatives are one of the important indicators in the democratization process of a country.

Given that cooperation and solidarity hold an important place in Şanlıurfa's and the whole of Turkey's socio-cultural structure, it is surprising that cooperative activities, which essentially serve the same purpose of cooperation and solidarity, are not sufficiently widespread and have not developed to the desired extent, both in Şanliurfa and entire Turkey. Although, there are many reasons for this, trust, transparent management, and inadequate participation based on lack of information about cooperatives are among the most important reasons. When the profiles of farmers in Şanlıurfa were evaluated regarding agricultural membership records, the least membership found in agricultural cooperatives by almost $40 \%$ among the others and more than half of them stated that they were not active members. Even though Şanlıurfa is the province with the third-highest agricultural potential in Turkey, the participation of its farmers in agricultural cooperative activities is quite limited.

According to the results of this research, barely one in every three farmers believes that cooperatives have a positive effect on agricultural income and displays a positive perception. Conversely, approximately one-third of farmers do not believe that cooperatives contribute to an increase in the agricultural income of farmers, that is, they showed negative perception. Again, more than onethird of farmers are undecided about the impact of cooperatives on farmers' agricultural income. Agricultural extension activities need to be intensified for undecided farmers on matters such as cooperative membership rights and benefits. Undecided farmers mostly do not know exactly what cooperatives are meant for, what services they provide, how to become a member, or how members can benefit from cooperatives. During the field research, farmers with negative perceptions about cooperatives stated that the administration of cooperatives often did not make the right economic decisions about protecting farmers' rights and was not transparent enough. Besides, a few farmers complained about the procedures of becoming a member. The farmers also stated that cooperative administrations are generally formed to agree with the tribal structure in the region the cooperative serves. The conclusion we can draw from this is that the decisions and representations are not sufficiently fair and democratic. In other words, there is a problem of trust among farmers.

A statistically positive significant relationship was found between each of the variables - age, marital status, non-agricultural income, experience, social security, farmer registration system, cooperative membership, and land - and the farmers' perception concerning the dependent variable. Conversely, a negative relationship was reported between each of the variables - education, income, and membership of other farmers' unions - and the dependent variable. No statistically significant relationship was reported between any of the variables - size of a farmer's household, the number of individuals engaged in agriculture in a farmer's family, the number of individuals working in non-agricultural jobs in the family, and the tenure on which the land was held - and the dependent variable. The perceptions towards cooperatives have a negative relationship with farmers' agricultural income and a positive relationship with land quantity. As agricultural income increases, farmer's need for cooperative decreases. It is also possible to say the opposite. Those who have non-agricultural income were around $25 \%$ and this income was not sufficient for their livelihoodis said by the farmers during the survey. For this reason, this group has a positive perception to generate more income based on agriculture. According to the observations obtained from the researches, large land assets do not mean more income. Therefore, special attention should be paid to farmers who have large pieces of land but low income. This is because farmers' decisions about cooperatives mostly driven by land and income.

Rural organizational models, which are in the form of cooperatives, can positively change the agricultural income and welfare levels of farmers. With these changes, positive socio-cultural contributions can be made to the social structure. A cooperative partnership can be made successful with the democratic participation and free expression of rational thinking individuals. However, the tribal structure, which has taken strong roots in the rural areas of Şanlıurfa, poses serious challenges to the positive changes that may occur in the social structure. A tribal system is a form of social and political organization that individuals create to meet their economic needs and ensure the security of life against external dangers. This organization model derives its power from the culture of obedience. Therefore, the presence of rational and free thinkers and democratic 
decision-makers in cooperative organizations is very rare in the rural area of Şanlıurfa. This situation adversely affects the establishment, membership, and sustainability of cooperatives.

As a result, there are conceptual, regional, cultural, educational, and structural problems faced by cooperatives in Şanlıurfa. To increase the participation of farmers, first of all, trust, transparent management, and public control are required. Then, awareness and training are required through agricultural extension services. These issues need to be given more attention by the public. This study is the first on this subject to be conducted in Şanliurfa. It is hoped that the results will provide useful information for researchers, decision-makers, and policy-makers in regions with similar socio-economic characteristics.

\section{ACKNOWLEDGEMENTS}

This research received no external funding.

\section{DECLARATION OF CONFLICTS OF INTERESTS}

The authors declare no conflict of interest. Sponsors had no role in the design of the study; in the collection, analysis or interpretation of data; in the writing of the manuscript and in the decision to publish the results.

\section{AUTHORS' CONTRIBUTIONS}

The author critically revised the manuscript and approved of the final version.

\section{REFERENCES}

ABDELRAHMAN, A. H.; SMITH, C. Cooperatives and agricultural development: A case study of groundnut farmers in Western Sudan. Community Development Journal, v.31, n.1, p.13-19, 1996. Available from: <https://www.jstor.org/ stable/44257245?seq=1\#metadata info tab contents $>$. Accessed: Apr. 11, 2020

ABEBAW, D.; HAILE, M. G. The impact of cooperatives on agricultural technology adoption: Empirical evidence from Ethiopia. Food Policy, v.38, p.82-91, 1 Fev 2013. Available from: $\quad<$ http://www.sciencedirect.com/science/article/pii/ S0306919212001030>. Accessed: May, 6, 2020. doi: 10.1016/j. foodpol.2012.10.003

ALÇIÇEK, G.; KARLI, B. Burdur ilinde tarımsal kooperatiflerde kooperatif-ortak iliskilerinin değerlendirilmesi. Mustafa Kemal Üniversitesi Ziraat Fakültesi Dergisi, v.21, n.1, p.83-91, 2016. Available from: <https://dergipark.org.tr/tr/pub/mkuzfd/ issue/24548/260028>. Accessed: Mar. 24, 2020.

ANONYMOUS. Türkiye Kooperatif̧̧ilik Raporu 2016. 2017. Available from: <http://koop.gtb.gov.tr/ data/592ea2dd 1 a79f514ac499aae/TKR-2016-2017\%20 0804-BASIM.pdf>. Accessed: May, 4, 2020.
ANONYMOUS. Türkiye'de Kooperatifçilik. 2020. Available from: $\quad<$ http://koop.gtb.gov.tr/kooperatifler-hakkinda/turkiyedekooperatifcilik>. Accessed: May, 1, 2020.

AYDOGDU, M. H. Evaluation of farmers' willingness to pay for agricultural extension services in GAP-Harran Plain, Turkey. Journal of Agricultural Science and Technology, v.19, n.5, p.785-796, 2017. Available from: <https://www.sid.ir/en/journal/ ViewPaper.aspx?id=539900>. Accessed: May, 5, 2020.

AYDOGDU, M. H.; YENIGÜN, K. Farmers' risk perception towards climate change: A case of the GAP- Sanliurfa Region, Turkey. Sustainability, v.8, n.8, p.806, 2016. Available from: $<$ https://doi.org/10.3390/su8080806>. Accessed: Apr. 12, 2020. doi: $10.3390 / \mathrm{su} 8080806$.

BANASZAK, I. Agricultural producer groups in Poland: Empirical survey results. Journal of Rural Cooperation, v.36, n.1, p.1-14, 2008. Available from: $<$ https://doi.org/10.22004/ag.econ.163449>. Accessed: Apr. 9, 2020. doi: 10.22004/ag.econ.163449.

BAYRAM, N. Sosyal Bilimlerde SPSS ile Veri Analizi. 6. ed. Bursa, Turkey: Ezgi Kitabevi, 2017. 218p.

BERNARD, T.; SPIELMAN, D. J. Reaching the rural poor through rural producer organizations? A study of agricultural marketing cooperatives in Ethiopia. Food Policy, Collective Action for Smallholder Market Access. v.34, n.1, p.60-69, 2009. Available from: <https://doi.org/10.1016/j.foodpol.2008.08.001>. Accessed: Apr. 24, 2020. doi: 10.1016/j.foodpol.2008.08.001

BERNARD, T. et al. Impact of cooperatives on smallholders commercialization behavior: Evidence from Ethiopia. Agricultural Economics, v.39, n.2, p.147-161, 2008. Available from: $<$ https:// doi.org/10.1111/j.1574-0862.2008.00324.x>. Accessed: Apr. 24, 2020. doi: $10.1111 / \mathrm{j} .1574-0862.2008 .00324 . x$.

BERNI, A. et al. Effect of vascular risk factors on increase in carotid and femoral intima-media thickness. Identification of a risk scale. Atherosclerosis, v.216, n.1, p.109-114, 2011. Available from: <https://doi.org/10.1016/j. atherosclerosis.2011.01.034>. Accessed: Feb. 14, 2020. doi: 10.1016/j.atherosclerosis.2011.01.034.

BORCARD, D. et al. Numerical Ecology with R. 2. ed. Cham, Switzerland: Springer, 2018. 435p.

CANÇELIK, M. et al. A research on the activities and problems of agro-based producers and breeder associations in Sanliurfa, Turkey. IOSR Journal of Business and Management (IOSRJBM), v.22, n.1/III, p.15-23, 2020. Available from: <https://doi. org/10.9790/487X-2201031523>. Accessed: Feb. 14, 2020. doi: $10.9790 / 487 X-2201031523$

CIKIN, A. Başka Bir Kooperatifçilik. 1. ed. İzmir, Turkey: TARIS \& Kanyılmaz, 2016. 156p

DOĞAN, H. et al. Farmers' willingness to pay for services to ensure sustainable agricultural income in the GAP-Harran Plain, Şanlıurfa, Turkey. Agriculture, v.10, n.5, p.152, 2020. Available from: <https://doi.org/10.3390/agriculture10050152>. Accessed: May, 10, 2020. doi: 10.3390/agriculture 10050152.

ERTEK, N. et al. Sığırcılık işletmelerinde kooperatif üyeliğini etkileyen faktörlerin analizi: TRA Bölgesi örneği. Alınteri Zirai Bilimler Dergisi, v.30, n.1, p.38-45, 2016. Available from:

Ciência Rural, v.51, n.3, 2021. 
$<$ https://dergipark.org.tr/tr/pub/alinterizbd/issue/24325/257758>. Accessed: Jan. 27, 2020.

FISCHER, E.; QAIM, M. Linking smallholders to markets: Determinants and impacts of farmer collective action in Kenya. World Development, v.40, n.6, p.1255-1268, 2012. Available from: $\quad<$ https://doi.org/10.1016/j.worlddev.2011.11.018>. Accessed: Apr. 8, 2020. doi: 10.1016/j.worlddev.2011.11.018.

FRANCESCONI, G. N.; HEERINK, N. Ethiopian agricultural cooperatives in an Era of global commodity exchange: Does organisational form matter?Journal of African Economies, v.20, n.1, p.153-177, 2010. Available from: <https://research.wur.nl/ en/publications/ethiopian-agricultural-cooperatives-in-an-era-ofglobal-commodity>. Accessed: Feb. 14, 2020.

GAP IDARESİ. Şanlıurfa İl Profili. 2019. Available from: <http:// www.gap.gov.tr/upload/dosyalar/pdfler/icerik/IL_profilleri/ SANLIURFA.pdf $>$. Accessed: May, 1, 2020.

GETNET, K.; ANULLO, T. Agricultural cooperatives and rural livelihoods: evidence from Ethiopia. Annals of Public and Cooperative Economics, v.83, n.2, p.181-198, 2012. Available from: $\quad<$ https://doi.org/10.1111/j.1467-8292.2012.00460.x>. Accessed: Apr. 22, 2020. doi: 10.1111/j.1467-8292.2012.00460.x.

GTHB. Stratejik Plan 2013-2017. 2013. Available from: $<$ https:// www.tarimorman.gov.tr/SGB/Belgeler/Stratejik\%20Plan\%20 2013-2017.pdf $>$. Accessed: Apr. 16, 2020.

GÜREŞÇI, E.; GÖNÇ, M. Türkiye'de kooperatiflerin temel sorunları ve çözüm önerileri üzerine düşünceler. Üçüncü Sektör Sosyal Ekonomi, v.52, p.219-229, 2017. Available from: $<$ https:// doi.org/10.15659/3.sektor-sosyal-ekonomi.17.12.815>. Accessed: Apr. 18, 2020. doi: 10.15659/3.sektor-sosyal-ekonomi.17.12.815.

HOKEN, H.; SU, Q. Measuring the effect of agricultural cooperatives on household income: Case study of a rice-producing cooperative in China. Agribusiness, v.34, n.4, p.831-846, 2018 Available from: <https://doi.org/10.1002/agr.21554>. Accessed: May, 2, 2020. doi: 10.1002/agr.21554.

INTERNATIONAL CO-OPERATIVE ALLIANCE. Facts and Figures. 2017. Available from: <https://www.ica.coop/en/ cooperatives/facts-and-figures $>$. Accessed: May, 6, 2020.

JOHNSON, R . A.; WICHERN, D. W. Applied Multivariate Statistical Analysis. 8. ed. New Jersey, United States of America: Pearson Education, 2007. 773p.

KAKAR, K. et al. Current situation and sustainable development of rice cultivation and production in Afghanistan. Agriculture, v.9, n.3, p.49, 2019. Available from: <https://doi.org/10.3390/ agriculture9030049>. Accessed: Mar. 5, 2020. doi: 10.3390/ agriculture 9030049 .

KALAYCI, Ș. SPSS Uygulamalaı Çok Değișkenli İstatistik Teknikleri. 5. ed. Ankara, Turkey: Asil Yayıncilık, 2010. 426p.

KARLI, B. et al. Factors affecting farmers' decision to enter agricultural cooperatives using random utility model in the South Eastern Anatolian Region of Turkey. Journal of Agriculture and Rural Development in the Tropics and Subtropics, v.107, n.2, p.115-127, 2006. Available from: <https://www.jarts.info/index. php/jarts/article/view/126>. Accessed: Mar. 9, 2020.
KOÇTÜRK, O. M. Türkiye'de kooperatiflerin vergilendirilmesi. Yönetim ve Ekonomi, v.13, n.2, p.119136, 2006. Available from: <http://static.dergipark.org.tr/ article-download/imported/5000069167/5000064071.pdf?> . Accessed: Feb. 21, 2020.

KÖROĞLU, S. Avrupa birliğinde ve Türkiye'de tarımsal örgütlenme. 2003. 177p. Master Thesis - T.C. Tarım ve Köyişleri Bakanlığı, Ankara, Turkey.

KROEKER, C. J. Individual, organizational, and societal empowerment: A study of the processes in a Nicaraguan agricultural cooperative. American Journal of Community Psychology, v.23, n.5, p.749-764, 1995. Available from: <https://doi.org/10.1007/ BF02506990>. Accessed: Apr. 1, 2020 doi: 10.1007/BF02506990.

KUMAR, V. et all. Role of cooperatives in improving livelihood of farmers on sustainable basis. American Journal of Educational Research, v.3, n.10, p.1258-1266, 2015. Available from: <https:// doi.org/10.12691/education-3-10-8>. Accessed: Feb. 14, 2020. doi: 10.12691/education-3-10-8.

LEAO, I. et al. Jobs from Agriculture in Afghanistan. Washington, DC, USA: The World Bank, 2018. Available from: $<$ http://elibrary.worldbank.org/doi/book/10.1596/978-1-46481265-1>. Accessed: Mar. 17, 2020.

LOIZOU, E. et al. The role of agriculture as a development tool for a regional economy. Agricultural Systems, v. 173, p. 482-490, 1 Jul. 2019. Available from: <https://doi.org/10.1016/j. agsy.2019.04.002>. Accessed: Apr. 27, 2020. doi: 10.1016/j. agsy.2019.04.002.

MA, W.; ABDULAI, A. Does cooperative membership improve household welfare? Evidence from apple farmers in China. Food Policy, v.58, p.94-102, 1 Jan 2016. Available from: <https://doi. org/10.1016/j.foodpol.2015.12.002>. Accessed: Jan. 14, 2020. doi: 10.1016/j.foodpol.2015.12.002.

MATHUR, N.; KASHYAP, S. P. Agriculture in Gujarat: Problems and prospects. Economic and Political Weekly, v.35, n.35/36, p.3137-3146, 2000. Available from: <https://www.jstor.org/ stable/4409679>. Accessed: May, 2, 2020.

McGREGOR, A. Rent extraction and the survival of the agricultural production cooperative. American Journal of Agricultural Economics, v.59, n.3, p.478-488, 1977. Available from: <https:// onlinelibrary.wiley.com/doi/abs/10.2307/1239649>. Accessed: Mar. 12, 2020.

MERT, M. SPSS STATA Yatay Kesit Veri Analizi Bilgisayar Uygulamaları. 1. ed. Ankara,Turkey: Detay, 2016. 320p.

ÖZDAMAR, K. Paket Programlar ile İstatistiksel Veri Analizi. 9. ed. Eskişehir, Turkey: Nisan Kitabevi, 2013. v. 1. 584p.

PRIMPAS, I. et al. Principal component analysis: Development of a multivariate index for assessing eutrophication according to the European water framework directive. Ecological Indicators, v.10, n.2, p.178-183, 2010. Available from: <https://doi.org/10.1016/j. ecolind.2009.04.007>. Accessed: Jan. 22, 2020. doi: 10.1016/j. ecolind.2009.04.007.

RAHMAN, T. M. Role of agriculture in Bangladesh economy: Uncovering the problems and challenges. International Journal of Business and Management Invention, v.6, n.7, p.36-46, 2017. 
Available from: <https:/www.ijbmi.org/papers/Vol(6)7/Version-3/ E0607033646.pdf>. Accessed: Apr. 9, 2020.

RIBAŠAUSKIENĖ, E. et al. Evaluating public policy support for agricultural cooperatives. Sustainability, v.11, n.14, p.3769, 2019. Available from: $<$ https://doi.org/10.3390/su11143769>. Accessed: Jan. 22, 2020. doi: 10.3390/su11143769.

SEVİNÇ, G. Süt sığırcılığı desteği alan kooperatif işletmelerinin örgütlenmeye ve kırsal kalkınmaya etkisi: Şanlıurfa ili KASDEP örneği / The effect of cooperative enterprises getting dairy cattle support on organization and rural development: Case of KASDEP of Sanliurfa province. 2018. 230p. PhD Thesis Harran University, Şanlıurfa, Turkey, 2018.

SEVINCC, G. et al. Farmers' attitudes toward public support policy for sustainable agriculture in GAP-Şanlıurfa, Turkey Sustainability, v.11, n.23, p.6617, 2019. Available from: <https:// doi.org/10.3390/su11236617>. Accessed: Jan. 22, 2020. doi: $10.3390 /$ su11236617.

SEXTON, R. J.; ISKOW, J. Factors Critical to the Success or Failure of Emerging Agricultural Cooperatives. Davis, California: Giannini Foundation Information Series No. 88-3, 1988. Available from: <https://pdfs.semanticscholar. org/30e0/1 f433c8171d92d448dbac18b3 feab7e8bbb2.pdf $>$. Accessed: Apr. 16, 2020.

SHARMA, S. Applied Multivariate Techniques. 10. ed. Newyork, United States of America: John Wiley \& Sons, Ltd, 1996. 512 p.

TABACHNICK, B. G.; FIDELL, L. S. Using Multivariate Statistics. 5. ed. New Jersey, United States of America: Allyn and Bacon, 2007. 983p.

THUVACHOTE, S. Cooperatives and Poverty Reduction in Thailand. 2011. Available from: <http://www.ipedr.com/vol22/1ICEBM2011-M00003.pdf>. Accessed: May, 3, 2020.

TUREK, R. et al. Research on The Association Benefits for The Agricultural Producer Market Manifestations. In: THE 3RD INTERNATIONAL SYMPOSIUM “AGRARIAN ECONOMY AND RURAL DEVELOPMENT - REALITIES AND
PERSPECTIVES FOR ROMANIA, 11 Oct. 2012, Bucharest, Romania. Anais... Bucharest, Romania: Bucharest: The Research Institute for Agricultural Economy and Rural Development (ICEADR), 11 Oct. 2012. p. 370-373. Available from: <https:// www.econstor.eu/bitstream/10419/76819/1/749488727.pdf>. Accessed: May, 6, 2020.

TURKSTAT. Farming Areas. 2019. Available from: $<$ http://www. tuik.gov.tr/PreTablo.do?alt_id=1001>. Accessed: Ap. 5, 2020.

TURKSTAT. Values of Crop and Animal Production. 2020a. Available from: <http://www.turkstat.gov.tr/UstMenu. do?metod=temelist $>$. Accessed: Apr. 5, 2020.

TURKSTAT. Main Business Income of Household Members in the Countryside. 2020b. Available from: <http://www.tuik.gov.tr/ PreTablo.do?alt_id=1011>. Accessed: Apr. 5, 2020.

VANDEPLAS, A. et al. Multinationals vs. cooperatives: The income and efficiency effects of supply chain governance in India. Journal of Agricultural Economics, v.64, n.1, p.217-244, 2013. Available from: <https://doi.org/10.1111/1477-9552.12004>. Accessed: Feb. 18, 2020. doi: 10.1111/1477-9552.12004.

VERHOFSTADT, E.; MAERTENS, M. Can agricultural cooperatives reduce poverty? Heterogeneous impact of cooperative membership on farmers' Welfare in Rwanda. Applied Economic Perspectives and Policy, v.37, n.1, p.86-106, 2015. Available from: <https://doi.org/10.1093/aepp/ppu021>. Accessed: Feb. 18, 2020. doi: 10.1093/aepp/ppu021.

YAVUZ, F.; DİLEK, Ş. Türkiye Tarımına Yeniden Bakış. 1. ed. İstanbul, Turkey: SETA Yayınları 137, 2019. 139p.

YU, G. Current Situation and Countermeasure Analysis of Rural Cooperative Economic Organizations in China. In: 2019 5TH INTERNATIONAL CONFERENCE ON ECONOMICS, MANAGEMENT AND HUMANITIES SCIENCE (ECOMHS 2019), 2019, Bangkok, Thailand. Anais... Bangkok, Thailand: Francis Academic Press, 2019. p.783-787.

ZEULI, K.; CROPP, R. Cooperatives: Principles and Practices in The 21st Century. 4. ed. Madison, USA: Cooperative Extension of University of Wisconsin, 2004. 90p. 